\title{
田窪千子 学位論文審査要旨
}

$\begin{array}{ccccc}\text { 主査 } & \text { 清 } & \text { 水 } & \text { 英 } & \text { 治 } \\ \text { 副主查 } & \text { 汐 } \text { 田 } \text { 剛 } \text { 史 } \\ \text { 同 } & \text { 領 } & \text { 家 } & \text { 和 } & \text { 男 }\end{array}$

\section{主論文}

Involvement of $\mathrm{N}$-acetyltransferase human in the cytotoxic activity of 5 -fluorouracil

（5-フルオロウラシルの細胞毒性活性におけるN-アセチルトランスフェラーゼの関与）

(著者：田窪千子、土谷博之、栗政明弘、Thomas Arnesen、領家和男、汐田剛史)

平成21年 Anti-Cancer Drugs 20巻 668頁～675頁 


\section{学 位 論 文 要 旨}

\section{Involvement of $\mathrm{N}$-acetyltransferase human in the cytotoxic activity of 5 -fluorouraci I （5-フルオロウラシルの細胞毒性活性におけるN-アセチルトランスフェラーゼの関与）}

蛋白質のアセチル化は、翻訳後修飾の一つである。ヒストンは、ヒストンアセチルトラ

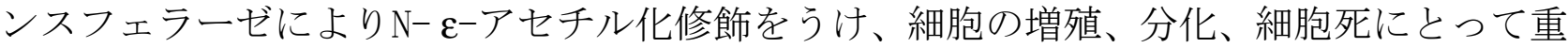

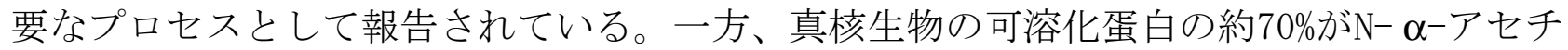

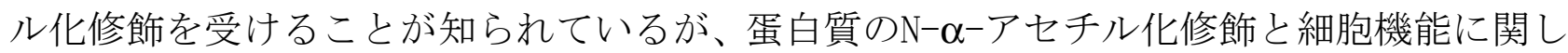
てはあまり知られていない。近年、この修飾に重要であるN- $\alpha$-acetyltransferase human （NATH）が甲状腺癌において正常組織に比べ高発現していることや、細胞死に関与するこ とが報告されている。本研究ではヒト頭頸部癌細胞においてNATH遺伝子が5-フルオロウラ シル (5-FU) 処理により発現が減弱することを見出だしており、ヒト頭頸部癌細胞株におい て5-FUの細胞毒性活性におけるNATHの関与と機能を検討した。

\section{方 法}

ヒト頭頸部扁平上皮癌細胞株HEp-2、ヒト舌癌細胞株HSC-3およびHSC-4、ヒト歯肉癌細胞 株Ca9-22、ヒト食道癌細胞株KYSE70、ヒト膵癌細胞株PANC-1、ヒト肝癌細胞株HuH-7、ヒト 大腸癌細胞株DLD-1を用いた。mRNA発現量はreal-time RT-PCRにより、細胞生存率はWSTア ッセイによりそれぞれ定量した。NATHの発現ベクターおよびsiRNAは、それぞれエレクトロ ポレーションおよびLipofectAMINE2000により細胞内へ導入した。アポトーシスの解析はフ ローサイトメーター、Hoechst33258染色およびウェスタンブロット（caspase-9、PARP）に より行った。また、NATH特異的siRNAおよび陰性対照siRNAをそれぞれ導入した細胞におい てプロテオーム解析を行った。

\section{結 果}

HEp-2細胞を5-FUを処理すると、NATH遺伝子発現量は、濃度および時間依存的に減少した。 また、NATH蛋白発現量も減少した。HEp-2、HSC-4、Ca9-22、KYSE70、HuH-7、 DLD-1の各 細胞において、5-FU処理によりNATH遺伝子発現量が減少した。一方、siRNAによりNATH遺伝 子発現を抑制すると、フローサイトメーターにおいて subG1の増大を認め、またHoechst 33258染色においてはNATH siRNA群で核の凝縮を認め、そしてウェスタンブロットにおいて 
はpro-caspase-9の減少と cleaved-PARPを認めたことから、NATH siRNAによりアポトーシ スが誘導されることが明らかとなった。一方、NATH遺伝子の強制発現により、HEp-2細胞の 増殖が促進された。5-FU処理とNATHの強制発現を同時に行うと、5-FUによる細胞死は部分 的に抑制された。また、siRNAによるNATH遺伝子発現の抑制により、thymidylate synthase (TS) 発現量は減少したが、5-FU処理では100 $\mu \mathrm{M} ゙$ のみTS発現量は低下した。HEp-2細胞株を 種々の抗癌剤（bleomycin、mitomycin C、nedaplatin、methotrexate）で処理した際、NATH 遺伝子発現量の減少を認めなかった。siRNAによるNATH発現抑制のすると、プロテオーム解 析により 34 蛋白質の発現変動を認めた。このうち18蛋白質は発現が上昇し、16蛋白質は発 現が低下していた。

\section{考 察}

ヒト頭頸部扁平上皮癌細胞株HEp-2は、5-FU処理によりNATH発現量が低下した。また、 siRNAによりNATH遺伝子発現量を抑制すると、アポトーシスが誘導された。さらに、NATH 遺伝子の強制発現により HEp-2細胞の増殖が促進されることや、5-FUの作用がNATHの強制発 現により一部抑制されたことから、5-FUの細胞毒性にNATH発現低下が関与することが示唆 された。また、5-FUの細胞毒性作用にTSが重要と報告されているが、NATH遺伝子発現抑制 によりTS遺伝子発現が抑制されることも明らかとなった。しかし、bleomycin、mitomycin C、 nedaplatin、methotrexateにより、NATH遺伝子発現量は変化しないことから、NATH遺伝子 低下は5-FUに特異性が高いことが示唆された。またプロテオーム解析にて発現低下した heat shock protein 70 (HSP70)、 enolase 1（EN01）や、発現増加したras-related nuclear protein (RAN) は大腸癌細胞株SW480において5-FU処理により同様の結果が報告されており、 これらの蛋白質の発現変動が5-FUの細胞毒性に関連している可能性が示唆された。

\section{結 論}

5-FUの細胞毒性活性の新規の作用機序として、NATHの発現低下が示唆された。 